\title{
Effects of garlic supplementation on in vitro nutrient digestibility, rumen fermentation and gas production
}

\author{
M.R. Kekana ${ }^{1 \#, ~ D . ~ L u s e b a ² ~ \& ~ M . C . ~ M u y u, ~}$ \\ 1 Institute for Animal Production, Department of Agriculture: Western Cape, PO Box 351, Oudtshoorn 6620, South Africa \\ ${ }^{2}$ Department of Animal Sciences, Faculty of Science, Tshwane University of Technology, Private Bag X 680, Pretoria \\ 0001, South Africa. \\ ${ }^{3}$ Animal Production Institute, Ruminant Nutrition, Agriculture Research Council, Pretoria, Private Bag X2, Irene 0062, \\ South Africa
}

\begin{abstract}
Garlic has secondary metabolites that possess antimicrobial properties that can alter nutrient digestibility and rumen fermentation similar to known antimicrobial products. The objectives of the study were to evaluate the effects of garlic powder and garlic juice on in vitro nutrient digestibility, rumen fermentation and gas production. The treatments were control no additives, garlic powder and garlic juice of $0.5 \mathrm{ml}$ and $1 \mathrm{ml}$. The digestibility of dry matter, crude protein and neutral detergent fibre were determined after $48 \mathrm{~h}$ incubation. Rumen ammonia nitrogen and volatile fatty acids were determined at $12 \mathrm{~h}$ and $24 \mathrm{~h}$ incubation. The cumulative gas production was recorded periodically over $48 \mathrm{~h}$. The in vitro dry matter disappearance decreased with $1 \mathrm{ml}$ of garlic juice compared to control. The crude protein degradability in garlic powder and garlic juice was lower than in control. The volatile fatty acids increased in all the treatments. Individual volatile fatty acids were significantly different, especially propionate, while the acetate:propionate ratio was reduced by garlic juice, and ammonia nitrogen was reduced by garlic powder and $0.5 \mathrm{ml}$ of garlic juice. The cumulative gas production increased significantly with both levels of garlic juice. The addition of garlic juice at $0.5 \mathrm{~mL} / 100 \mathrm{~mL}$ could enhance the production of propionate, and reduce the acetate:propionate ratio implying that the supply of hydrogen for methanogens is limited.
\end{abstract}

Key words: garlic juice, garlic powder, volatile fatty acids, ruminants

"Email: molatelom@elsenburg.com

\section{Introduction}

In livestock production systems, pharmaceutical technologies like antimicrobials are commonly used to increase the average daily gain and improve feed efficiency; they also prevent disease and metabolic disorders (McGuffey et al., 2001). Antimicrobial ionophores have been used extensively to manipulate the rumen microbial population, increase propionate, reduce dietary protein deamination and decrease methane production (Broderick, 2004; Odongo et al., 2007). Despite the positive nutritional and health effects of antimicrobials, there are increasing public and scientific concerns about their use in animal feed. These concerns are fuelled by resistant bacteria in both animals and humans (Marshall \& Levy, 2011), the presence of residues in milk and carcasses (Benchaar et al., 2008) and the release of contaminating residues into the environment (Yang \& Carlson, 2004), all of which pose a serious risk to public health. As a result, certain countries have banned their use in animal feed (Benchaar et al., 2008).

Considerable effort has been made toward developing potential alternatives that might improve feed efficiency and mitigate gas emission. In recent years, there has been a growing interest in evaluating plants and their extracts (Windisch et al., 2009). Garlic has been used as a spice and native medicine throughout human history (Revlin, 2001). Garlic contains many secondary metabolites with antimicrobial properties (Kasuga et al., 2001; Amagase, 2006) and may be useful in improving rumen fermentation. Garlic powder contains alliin and oil soluble sulphur compounds but without allicin (Amagase et al., 2001) whereas garlic juice have allicin without alliin (Kasuga et al., 2001). The presence antimicrobial alliin and allicin in garlic enable it to decreases acetate, increases propionate production and improves the efficiency of nutrient use by decreasing methane production and ammonia in vitro (Cardozo et al., 2005; Busquet et al., 2006; Kamel et al., 2008). However, the effects of garlic and its derivatives on rumen, the microbial population and ruminal fermentation are not consistent (Cardozo et al., 2005; Kongmun et al., 2010). There are discrepancies in various studies which are attributed to the differences in types and doses of antimicrobial compounds in garlic. For example garlic powder and garlic oil had no effect on dry matter digestibility both in vitro and in vivo (Busquet et al., 2005a, b; Wanapat et al., 2008; Kongmun et al., 2010). Ahmed et al. (2009) reported that inclusion of garlic juice at $2.5 \%$ improved the digestibility of dry matter but at a dose of $7.5 \%$, dry matter digestibility was reduced. Therefore, the present study was conducted to evaluate the effects of garlic powder 
and garlic juice on in vitro gas production, digestibility and fermentation end products of a basal concentrate dairy diet.

\section{Materials and methods}

Garlic cloves were washed, peeled and blended for one minute using Waring Blender $\AA^{\circ}$. The extract was transferred into a strainer and floating debris was removed. Garlic juice was filtered through a nylon cloth to separate the remaining pulp from the pure juice. Fresh rumen fluid was provided by the Agricultural Research Council-Dairy section. Two early-lactating Holstein cows were used as donors of rumen fluid for the in vitro experiments. The animals were fed an early lactating diet as total mixed ration provided twice daily ( $09 \mathrm{~h} 00$ and 14h00) on ad libitum (Table 1). The animals were restrained in a crush pen prior to collection. The protocol for care and collection of the rumen fluid was accepted by the ARC-animal ethics committee. The diet was formulated to meet nutrient requirements of the cows (NRC, 2001). Rumen fluid was collected from each Holstein dairy cow through a cannula. The flask was pre-warmed by filling it with hot water to limit temperature loss. It was emptied prior to collection. Both the liquid and the solid contents were removed by hand from the cannula. The solid contents were to ensure the inclusion of fibrolytic bacterial species. Pooled rumen content was squeezed through four layers of cheesecloth into the thermos flask and the solid rumen contents were then mixed with the rumen fluid in the flask. The flask was filled completely to eliminate oxygen (Mauricio et al., 1999). After collection, the flask was immediately transported to the laboratory. The strained rumen fluid was continuously purged under free oxygen $\mathrm{CO}_{2}$ and kept at $39^{\circ} \mathrm{C}$. The $\mathrm{pH}$ was measured and buffer solution was prepared according to recommendations by Goering \& Van Soest (1970). The magnetic stir bar was placed in the jar to make the solution homogeneous. The treatments were control no additives (C), garlic powder (GP, $53 \mathrm{mg})$ and garlic juice at two levels ((GJ1) 0.5 and (GJ2) $1 \mathrm{~mL})$.

The nylon bags (ANKOM Technology R510), with a pore size of $50 \mu \mathrm{m}$, were used in the trial using an ANKOM Daisy" incubator (ANKOM Technologies Corp., Fairport, NY). The bags were filled with samples of $0.5 \mathrm{~g}$ of the diet (Table 1) and sealed using impulse sealer. The bags were incubated in triplicate for $0 \mathrm{~h}, 2 \mathrm{~h}$, $4 \mathrm{~h}$, and $8 \mathrm{~h}$. Since incubation times which were longer than $12 \mathrm{~h}$ were not expected to leave sufficient residue for chemical analysis, quintuplicate bags were prepared for $12 \mathrm{~h}, 24 \mathrm{~h}, 36 \mathrm{~h}$ and $48 \mathrm{~h}$ incubation times. At the end of the incubation, the bags were removed from the incubator and the solution was discarded. The bags, including the zero samples, were immediately washed with cold tap water until the water became clear. All the bags were then dried in a forced air drying oven at $60^{\circ} \mathrm{C}$ for 48 hours. From the quintuplicate bags, triplicate bags were combined for analyses of crude protein (CP) using the Micro-Kjeldahl method (AOAC, 2000) and duplicate bags were kept for neutral detergent fibre (NDF) analyses (Van Soest \& Robertson, 1985). Ruminal in vitro disappearance of dry matter (DM) was calculated as the difference between the amount in the original sample and in the residue. The dry matter and crude protein disappearance data were used to estimate ruminal kinetic parameters using the exponential model:

$$
P=a+b\left[1-e^{c t}\right]
$$

where $\mathrm{P}=$ potential degradability at time $\mathrm{t} ; \mathrm{a}=$ rapidly degradable fraction; $\mathrm{b}=$ slowly degradable fraction; $\mathrm{c}=$ constant rate at which the fraction described by $b$ is degraded per $h$ and $t=$ time of incubation. Ruminal effective degradability (ED) of DM and CP at a rumen flow rate $(k)$ with three in rumen flow rate of $0.02 \mathrm{~h}, 0.05 \mathrm{~h}$ and $0.08 \mathrm{~h}$ was estimated using the equation:

$$
E D=\frac{a+b x c}{c+k}
$$

where $a, b$ and $c$ as described above (Theodorou et al., 1994).

Incubations were conducted in $250 \mathrm{~mL}$ glass bottles. The bottles were rinsed with distilled water and flushed with $\mathrm{CO}_{2}$ before $0.5 \mathrm{~g}$ of substrate and $100 \mathrm{~mL}$ of buffered fluid were added. Triplicate bottles were incubated for each treatment and each incubation time (12 and $24 \mathrm{~h})$. The temperature of the bottles was raised to $39^{\circ} \mathrm{C}$ prior to incubation by putting them in the water bath. After incubation, bottles were placed in cold water and $4 \mathrm{~mL}$ were sampled for analysis of volatile fatty acids (VFAs) and ammonia nitrogen $\left(\mathrm{NH}_{3}-\mathrm{N}\right)$. The samples were stored at $-20^{\circ} \mathrm{C}$ until analysed. Techniques used for gas production were based on the Reading Pressure Technique (Theodorou et al., 1994; Mauricio et al., 1999) with automated gas pressure devices from the ANKOM system. The bottles were fitted with ANKOM ${ }^{\mathrm{RF}}$ gas production system modules (ANKOM ${ }^{\circledR}$ Technologies corp., Fairport, NY) and placed in an incubator for $48 \mathrm{~h}$ and the temperature was maintained at $39^{\circ} \mathrm{C}$. Incubations were conducted in $250 \mathrm{~mL}$ glass bottles similar to the once used in fermentation. The initial gas was recorded and thereafter, every $4 \mathrm{~h}$. The values recorded were converted to millilitres of gas produced as stated by the ANKOM system. Samples of the total mixed ration were dried at $60^{\circ} \mathrm{C}$ for $48 \mathrm{~h}$ and then grind through a $1 \mathrm{~mm}$ screen. The dry matter of feed was determined following the procedures of Goering \&Van Soest (1970). Crude protein was determined using the Kjeldahl method. Neutral detergent fibre of all samples was determined following the procedure of Van Soest \& Robertson (1985). 
Table 1 Diet and chemical composition of total mixed ration supplemented with garlic

\begin{tabular}{ll}
\hline Ingredients & $\%$ DM \\
\hline Eragrostis grass & 13.08 \\
Molasses cane & 12.34 \\
Hominy chop & 3.74 \\
Wheat bran & 7.37 \\
Urea & 0.41 \\
Maize grain coarse & 32.89 \\
Minvit ${ }^{1}$ & 0.41 \\
Salt & 0.20 \\
Lucerne & 18.69 \\
Cotton seed meal & 10.70 \\
Chemical composition & \\
Fat & 3.3 \\
CP & 15.91 \\
Ca & 0.66 \\
P & 0.43 \\
K & 1.50 \\
Mg & 0.31 \\
ME, MJ/Kg DM & 2.53 \\
\hline
\end{tabular}

${ }^{1}$ minerals and vitamins; ME: metabolisable energy

All the parameters measured were analysed by ANOVA using the General Linear Model procedure of SAS (2009). The a, b, c and ED were estimated by using the model of nonlinear regression procedure (NLIN) using SAS. The average NDF disappearance of GP, GJ1 and GJ2 were each statistically compared with the control. GJ2 was compared with GJ1 by using two independent t-tests.

\section{Results}

The effect of garlic powder and garlic juice (Table 2) resulted in differences $(p<0.05)$ on DM and CP degradation suggesting that the two products differ in their active components as demonstrated by different digestion patterns. There were no significant differences between the treatments on NDF disappearance ( $p>0.05)$ suggesting that neither garlic powder nor garlic juice had any effect on fibre digestion.GJ1 reduced $(p<0.05)$ CP degradation than GP and GJ2. The change of CP disappearance over time is illustrated in Figure 1. The relationship between DM and CP disappearance are shown in Figure 2. The mean in DM and CP were 0.2587 and 0.7966 respectively and showed a strong positive relationship $\left(R^{2}=0.81 ; p<0.001\right)$. The GJ1 resulted in lower ammonia $\mathrm{N}(\mathrm{p}<0.05)$ and higher cumulative gas production $(\mathrm{p}<0.05)$ compared to control, GP and GJ2 (Table 3). Garlic treatments increased the total VFAs as compared to control $(p<0.05)$ and did not affect the molar proportion of acetate $(p>0.05)$. The juice treatments resulted in higher molar proportion of propionate $(p<0.05)$. Butyrate proportion was lower in GP $(p<0.05)$ and higher in C and GJ1 $(p<0.05)$. The molar proportion of iso-valerate and iso-butyrate was lower $(p<0.05)$ in GP as compared to control group.

Table 2 Effect of garlic powder and garlic juice on dry matter, crude protein digestibility and neutral detergent fibre in vitro

\begin{tabular}{llllll}
\hline Parameters & \multicolumn{4}{c}{ Treatments } & SEM \\
\cline { 2 - 4 } & C & GP & GJ1 & GJ2 & \\
\cline { 1 - 4 } Dry matter & 50.3 & 47.9 & 46.7 & 44.8 & 5.21 \\
A & $30.6^{\mathrm{b}}$ & $32.2^{\mathrm{b}}$ & $37.2^{\mathrm{ab}}$ & $41.2^{\mathrm{a}}$ & 3.83 \\
B & 0.074 & 0.100 & 0.072 & 0.068 & 0.04 \\
C & $74.4^{\mathrm{a}}$ & $74.7^{\mathrm{a}}$ & $73.2^{\mathrm{ab}}$ & $70.6^{\mathrm{b}}$ & 1.02 \\
ED2 & $68.7^{\mathrm{ab}}$ & $69.3^{\mathrm{a}}$ & $66.7^{\mathrm{bc}}$ & $64.8^{\mathrm{c}}$ & 2.23 \\
ED5 & $65.3^{\mathrm{ab}}$ & $65.7^{\mathrm{a}}$ & $62.5^{\mathrm{bc}}$ & $61.2^{\mathrm{c}}$ & 1.93 \\
ED8 & & & & & \\
Crude protein & & & & & \\
A & $39.2^{\mathrm{a}}$ & $33.2^{\mathrm{c}}$ & $32.3^{\mathrm{d}}$ & $38.4^{\mathrm{b}}$ & 0.64 \\
B & $32.4^{\mathrm{a}}$ & $26.7^{\mathrm{b}}$ & $27.4^{\mathrm{b}}$ & $26.0^{\mathrm{b}}$ & 0.54
\end{tabular}




$\begin{array}{llllll}\text { C } & 0.090^{\mathrm{b}} & 0.086^{\mathrm{b}} & 0.063^{\mathrm{c}} & 0.153^{\mathrm{a}} & 0.01 \\ \text { ED2 } & 65.7^{\mathrm{a}} & 54.8^{\mathrm{c}} & 53.1^{\mathrm{d}} & 61.3^{\mathrm{b}} & 1.09 \\ \text { ED5 } & 60.0^{\mathrm{a}} & 50.1^{\mathrm{c}} & 47.6^{\mathrm{d}} & 57.9^{\mathrm{b}} & 1.12 \\ \text { ED8 } & 56.3^{\mathrm{a}} & 47.1^{\mathrm{c}} & 44.3^{\mathrm{d}} & 55.4^{\mathrm{b}} & 1.12 \\ \text { NDF disappearance } & 53.0 & 56.5 & 54.8 & 52.7 & 3.29\end{array}$

C: control; GP: garlic powder; GJ1: garlic juice at low dose; GJ2: garlic juice at high dose; ED: effective degradability rates $(0.02 \mathrm{~h}, 0.05 \mathrm{~h}$ and $0.08 \mathrm{~h})$.

abcd Means within a row with different superscripts differ $(p<0.05)$.

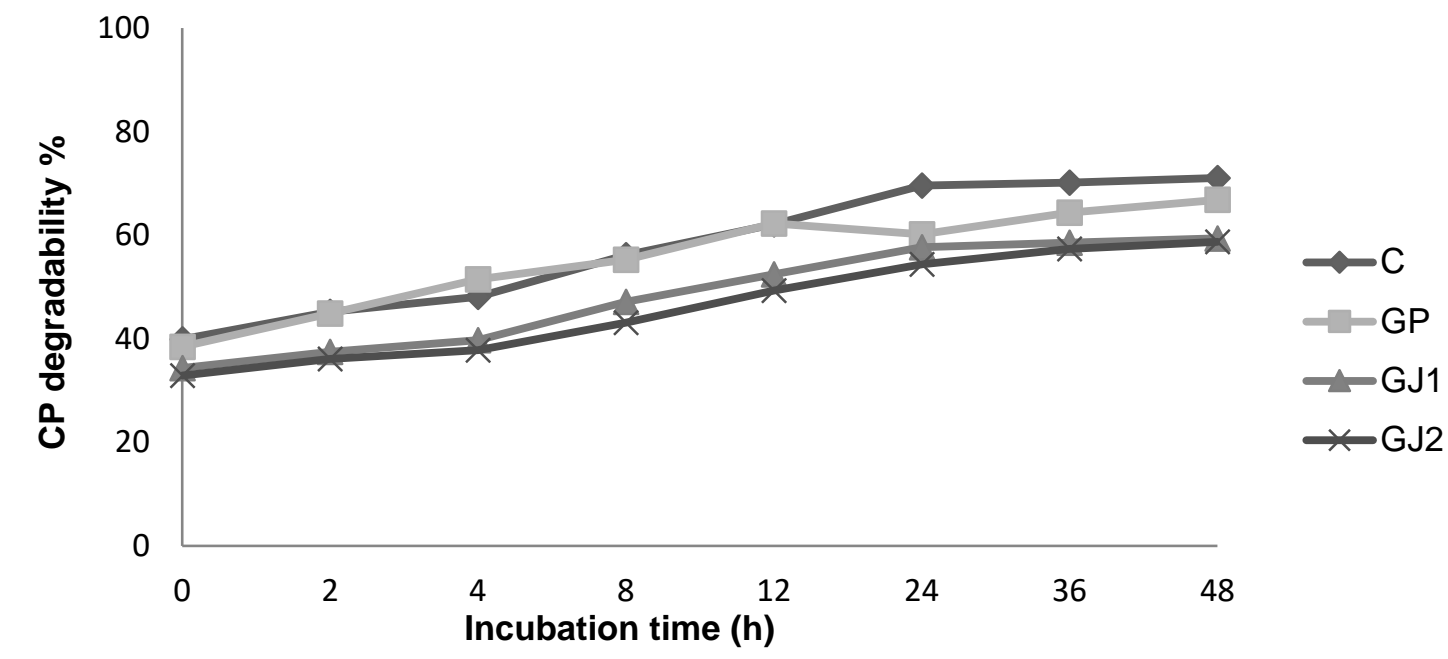

Figure 1 Change of crude protein disappearance as affected by garlic supplementation

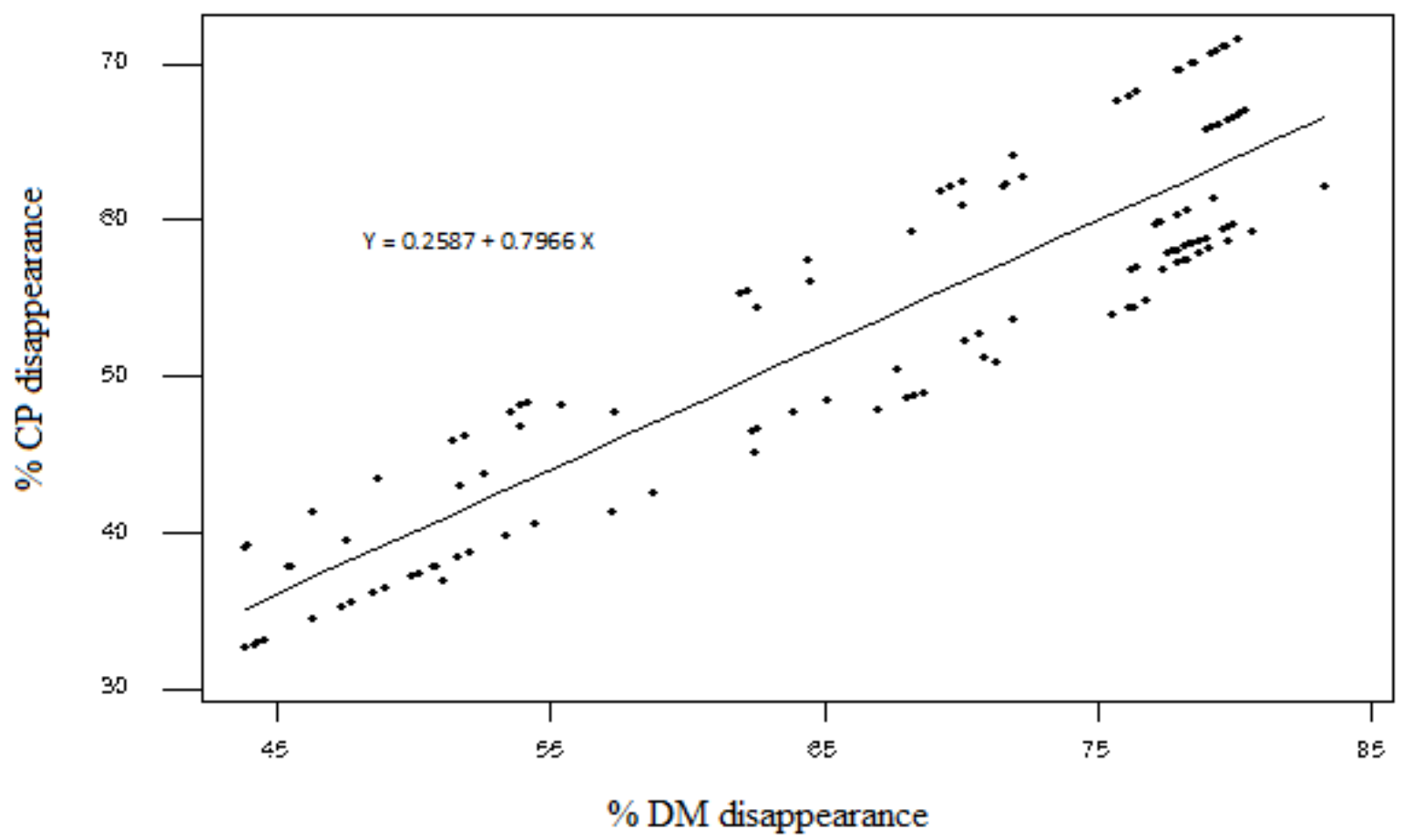

Figure 2 The relationship between dry matter and crude protein disappearance 
The cumulative gas production did not differ at the first 4 hours. Increased gas production was observed during the first $8 \mathrm{~h}$ incubation for all the treatment groups (Figure 3). From $12 \mathrm{~h}$ through to the end of the incubation period, cumulative gas production was higher in GJ1 and lower in GP than in the rest of the treatments.

Table 3 Rumen parameters as affected by in vitro supplementation of garlic powder and garlic juice

\begin{tabular}{llllll}
\hline Parameters & \multicolumn{4}{c}{ Treatments } & SEM \\
\cline { 2 - 5 } & $\mathrm{C}$ & $\mathrm{GP}$ & \multicolumn{1}{c}{ GJ1 } & GJ2 & \\
\hline $\mathrm{NH}_{3}-\mathrm{N}$ & $6.9^{\mathrm{a}}$ & $6.7^{\mathrm{b}}$ & $6.3^{\mathrm{c}}$ & $6.8^{\mathrm{ab}}$ & 1.25 \\
Gas (mL) & $42.8^{\mathrm{c}}$ & $34.50^{\mathrm{d}}$ & $94.90^{\mathrm{a}}$ & $71.90^{\mathrm{b}}$ & 0.60 \\
Total VFA (mmol/L) & $128.3^{\mathrm{c}}$ & $133.8^{\mathrm{b}}$ & $135.5^{\mathrm{a}}$ & $136.5^{\mathrm{a}}$ & 0.74 \\
Proportion of volatile fatty acids (\%) & & & & & \\
$\quad$ Acetate & 62.7 & 62.4 & 62.2 & 62.5 & 0.08 \\
Propionate & $16.5^{\mathrm{b}}$ & $16.9^{\mathrm{b}}$ & $18.2^{\mathrm{a}}$ & $18.2^{\mathrm{a}}$ & 0.30 \\
Butyrate & $14.3^{\mathrm{a}}$ & $13.1^{\mathrm{b}}$ & $14.5^{\mathrm{a}}$ & $13.5^{\mathrm{ab}}$ & 0.17 \\
Valerate & $1.5^{\mathrm{ab}}$ & $1.4^{\mathrm{b}}$ & $1.6^{\mathrm{a}}$ & $1.5^{\mathrm{ab}}$ & 0.01 \\
Iso-valerate & $2.8^{\mathrm{a}}$ & $2.5^{\mathrm{b}}$ & $2.8^{\mathrm{a}}$ & $2.7^{\mathrm{ab}}$ & 0.04 \\
Iso-butyrate & $1.7^{\mathrm{a}}$ & $1.6^{\mathrm{b}}$ & $1.7^{\mathrm{a}}$ & $1.6^{\mathrm{ab}}$ & 0.02 \\
C2:C3 ratio & $3.8^{\mathrm{a}}$ & $3.6^{\mathrm{a}}$ & $3.4^{\mathrm{b}}$ & $3.4^{\mathrm{b}}$ & 0.03 \\
\hline
\end{tabular}

C: control; GP: garlic powder; GJ: garlic juice at low dose; GJ2: garlic juice at high dose;

VFA: volatile fatty acids, $\mathrm{C} 2: \mathrm{C} 3$ = acetate:propionate ratio

abcd Means within a row with different superscripts differ $(p<0.05)$.

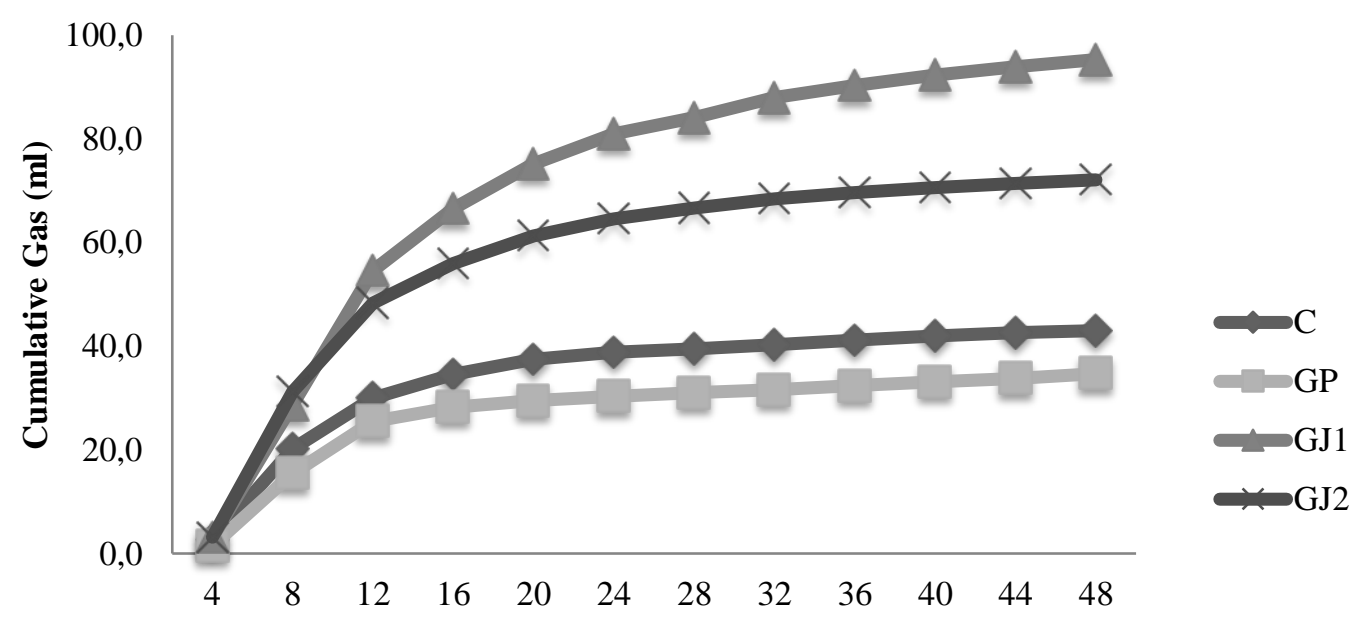

Incubation time (h)

Figure 3 Cumulative gas production affected by garlic powder and garlic juice

\section{Discussion}

Natural plant extracts may be the alternative to ruminal modifiers. In the present study, the effect of garlic powder and garlic juice on DM digestibility resulted in significant differences among the garlic treatments, suggesting different activities when it comes to the microbes and digestion. Our results of garlic powder were in accord with the findings of other reports who observed no changes in DM digestibility (Wanapat et al., 2008; Kongmun et al., 2010). Similar results were reported with garlic oil, diallyl disulfide (DAD) and allyl mercaptan at different doses (Busquet et al., 2005b). Compared with the control, garlic juice supplemented at $1 \mathrm{~mL}$ reduced the digestion of DM. Likewise, the effect of high level of garlic juice on DM digestibility agrees with in vivo findings of Ahmed et al. (2009), when garlic was supplied at $2.5 \%$ vs $7.5 \%$ in buffaloes. In their study, garlic juice supplemented at $7.5 \%$ dramatically reduced DM digestibility.

In our study, supplementation of garlic powder and doses of garlic juice affected CP degradation differently. Compared to control, all garlic supplements reduced the effective ruminal protein degradation. GJ1 
reduced CP degradation more than GP and GJ2. Ferme et al. (2004) observed that garlic modified the microbial population profile by reducing the contribution of Prevotella species, which are responsible for protein degradation and amino acid (AA) deamination in the rumen. In general, when proteins are protected from rumen deamination, ammonia decreases and ruminants may have more AA available for absorption. The effects observed in the present study confirm the mechanism whereby garlic interacts with sulfhydryl groups of protein and their biological active components (Reuter et al., 1996). In contrast to our study, other reports observed no effect of garlic on protein degradation (Cardozo et al., 2004; Busquet et al., 2005a, b). The difference in responses on protein degradation in comparison with the present study may be attributed to the dose used (i.e. $300 \mathrm{mg} / \mathrm{L}$ vs $530 \mathrm{mg} / \mathrm{L}$ ), the type of extracts (i.e. oil vs, powder vs juice), the type of diet (i.e. TMR vs hay: concentrate vs forage). Additionally, the length of incubation might have played a major role. For example, the experimental periods from Busquet et al. (2005a) and Cardozo et al. (2004) were longer (9 and 10 days) compared to the present study with 2 days of incubation. Cardozo et al. (2004) also suggested that the inconsistent results may be attributed to differences in the rate of protein degradation, the rate of peptide use by rumen microbes that depend on the availability of energy, and the rate of peptide $\mathrm{N}$. The researchers Bach, Calsamiglia, and Stern (2005) explain that factors such as the type of protein, rumen dilution rate, $\mathrm{pH}$ and the predominant species of rumen microbes affect the process of protein degradation. Hart et al. (2007) suggested that the main effects of plant extracts in the rumen are the reduction of protein and starch degradation and the inhibition of amino acid degradation owing to the selection of certain bacteria. These effects are favourable in adult ruminants because nutritionists focus on additives with the potential to reduce ruminal protein degradation by reducing proteolysis, peptidolysis or deamination, which increase propionate production and decrease acetate and methane production without reducing the total VFA production (Kamel et al., 2008). Compared to control, supplementation of garlic had no effect on NDF digestibility suggesting no activities on fibre digestion.

In the present study, garlic supplementation increased the total VFA in comparison to the control. Volatile fatty acids are the end products of rumen fermentation and represent the main supply of energy for ruminants, and their reduction would be nutritionally unfavourable. In agreement with the present study, Cardozo et al. (2005) reported increased total VFA by garlic supplementation. In contrast, a decrease or no effect from garlic on the total VFA concentration had been reported (Cardozo et al., 2004; Yang et al., 2007; Wanapat et al., 2008; Kongmun et al., 2010; Kongmun et al., 2011). The antimicrobial activity of garlic has been attributed to its sulphur compounds, particularly allicin (Ankri \& Mirelman, 1999) and increase with an additional S atom (Reuter, Koch \& Lawson, 1996; Ross et al., 2001). Garlic juice contains allicin (Kasuga et al. (2001), which might have contributed to the effect in the present study, due to the short experimental period. This explains why garlic juice, which contains allicin ( $2 \mathrm{~S}$ atoms) resulted in a stronger effect than that of GP, which contains alliin (1 $\mathrm{S}$ atom). None of the garlic extracts at the dose evaluated affected the molar proportion of acetate. In the present study, only garlic juice increased the molar proportion of propionate compared with the control. The addition of GP did not affect the molar proportion of propionate compared to control group. The increase in propionate proportions with garlic juice concurs with several in vitro studies (Busquet et al., 2005a, b; 2006; Kongmun et al., 2010) that consistently indicated that garlic increased the proportion of propionate. In contrast, other studies reported no effects or decreased effects in the molar proportion of propionate (Wanapat et al., 2008; Anassori et al., 2012).

In concurrence with the present study, Anassori et al. (2012) observed a decrease in butyrate with raw garlic and an increase with garlic oil. According to lberl et al. (1990) raw garlic contains the same ingredient found in GP, but the proportion and amount of the various compounds differ owing to the loss of compounds during dehydration of garlic powder (Amagase et al., 2001). Other studies observed an increase in butyrate concentrations with garlic oil supplemented and suggested a consistency with fermentation profiles of methane inhibitors (Martin \& Macy, 1985). Busquet et al. (2005b) observed no effect of garlic oil and its compounds on the molar proportion of iso-butyrate and increased valerate proportion. Branched volatile fatty acids are derived from amino acid catabolism in the rumen (Mackie \& White, 1990). The ratio of C2:C3 was significantly lowest when it was supplemented with GJ1 and GJ2, but increased in GP. Similar effects were observed in other studies (Busquet et al., 2006; Wanapat et al., 2008). The mechanism by which garlic extracts exert their antimicrobial effect on the molar proportion of VFA is not generally understood. GJ1 and GP reduced the NH3$\mathrm{N}$ concentration, while high doses increased NH3-N concentration, suggesting that GP and GJ1 inhibited AA deaminase activity. The inhibition of AA deamination has an impact on in vivo because it may increase the ruminal escape of dietary protein and improve the efficiency of $\mathrm{N}$ use in the rumen (Van Nevel \& Demeyer, 1988). In contrast, in vivo studies reported no effect on ruminal NH3-N when garlic was fed to dairy cattle which 
might be explained by the need for an adaptation period by microbes in long-duration experiments and allow the replacement of the inhibited microbial population by other resistant bacterial groups (Yang et al., 2007; Wanapat et al., 2008). However, the concentration of NH3-N in the rumen may increase (Hristov et al., 1999) or decrease (Devant et al., 2000) depending on several factors, including the amount of degradable protein and the amount and type of dietary carbohydrates available for microbial use (Russell et al., 1983). GJs had the lowest $\mathrm{C} 2: \mathrm{C} 3$ ratio compared to control and GP. As noted with yeast, this might be due to the limiting effect of GJ on hydrogen metabolism in the rumen (Polyorach et al., 2014). The presence of concentrate in the diet changes ruminal VFAs concentrations in such way that less C2 and more C3 are produced.

Cumulative gas production was reduced by garlic powder. These results suggested that garlic powder had a weaker inhibition effect on fermentation rate. There are consistent with those of Kongmun et al. (2010) who reported a decrease in cumulative gas production when garlic powder was supplemented. Similarly, Anassori et al. (2012) reported a decrease in gas production with raw garlic and garlic oil. This could be explained by loss of main active ingredient in garlic powder during dehydration (Amagase et al., 2001). Low level of garlic juice had shown the potential to modify ruminal fermentation and to increase gas production level. The increased gas production was supported by increased DM digestibility. This is in agreement with Cullen et al. (2005) who reported that high level of garlic reduced DM digestibility. The amount of cumulative gas produced in the rumen depends on the quantity of substrate fermented and the amount and molar proportions of the VFA produced (Davies et al., 2000). In the present results, GJ1 and GJ2 increased the total VFA, which confirms the high value for gas production.

\section{Conclusion}

Garlic extracts may be useful in improving the efficiency of nutrient utilization in ruminants. Garlic supplements reduced crude protein degradability and increased the total VFA. These results suggest that the supplementation of GJ1 would be the best in improving propionate production and reduction of NH3-N, and acetate:propionate ratio. Further studies are required to evaluate the effect of garlic extracts on number of beneficial microbes in the rumen and active compounds in the extracts and the effective doses in vivo.

\section{References}

AOAC, 2000. Official methods of analysis. Association of Official Analytical Chemists International. Maryland, USA.

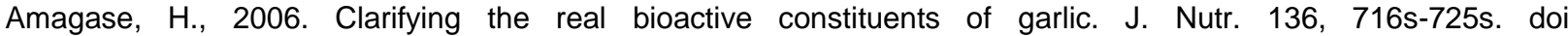
10.1093/jn/136.3.716S

Amagase, H., Petesch, B.L., Matsuura, H., Kasuga, S. \& Itakura, Y., 2001. Intake of garlic and its bioactive components. J Nutr. 131, 955s-962s. doi 10.1093/jn/131.3.955S

Anassori, E., Dalir-Naghadeh. B., Pirmohammadi, R., Taghizadeh, A., Asri-Rezaei, S., Farahmand-Azar, S., Besharati, M. \& Tahmoozi, M., 2012. In vitro assessment of the digestibility of forage based sheep diet, supplemented with raw garlic, garlic oil and monensin. Vet. Res. Forum. 3(1), 5-11.

Ankri, S. \& Mirelman, D., 1999. Review: antimicrobial properties of allicin from garlic. Microbes. Infect. 2, $125-129$. doi 10.1016/S1286-4579(99)80003-3

Ahmed, A.A., Bassuony, N.I, Awad, E.S., Aiad, A.M. \& Mohamed, S.A., 2009. Adding natural juice of vegetables and fruitage to ruminants' diets (B) nutrients utilization, microbial safety and immunity, effect of diets supplemented with lemon, onion and garlic juice fed to growing buffalo calves. World J. Agric. Sci., 5(4):456-465.

Bach, A., Calsamiglia, S. \& Stern, M., 2005. Nitrogen metabolism in the rumen. J. Dairy Sci. 88, E9-E21. doi 10.3168/jds.S0022-0302(05)73133-7

Benchaar, C., Calsamiglia, S., Chaves, A.V., Fraser, G.R., Colombatto, D., Mcallister, T.A. \& Beauchemin, K.A., 2008. A review of plant-derived essential oils in ruminant nutrition and production. Anim. Feed. Sci. Tech. 145, $209-228$. doi 10.1016/j.anifeedsci.2007.04.014

Broderick, G.A., 2004. Effect of low level monensin supplementation on the production of dairy cows fed alfalfa silage. J. Dairy Sci. 87:359-368. doi: 10.3168/jds.S0022-0302(04)73175-6

Busquet, M., Calsamiglia, S., Ferret, A. \& Kamel, C., 2006. Plant extracts affect in vitro rumen microbial fermentation. J. Dairy Sci. 89, 761-771. doi: 10.3168/jds.S0022-0302(06)72137-3

Busquet, M., Calsamiglia, S., Ferret, A., Cardozo, P.W. \& Kamel, C., 2005a. Effects of cinnamaldehyde and garlic oil on rumen microbial fermentation in a dual flow continuous culture. J. Dairy Sci. 88, 2508-2516. doi: 10.3168/jds.S0022-0302(05)72928-3

Busquet, M., Calsamiglia, S., Ferret, A., Carro, M.D. \& Kamel, C., 2005b. Effect of garlic oil and four of its compounds on microbial fermentation. J. Dairy Sci. 88(12), 4393-4404. doi: 10.3168/jds.S0022-0302(05)73126-X 
Cardozo, P.W., Calsamiglia, S., Ferret, A. \& Kamel, C., 2004. Effects of natural plant extracts on ruminal protein degradation and fermentation profiles in continuous culture. J. Anim. Sci. 82, 3230-3236. doi: 10.2527/2004.82113230x

Cardozo, P.W., Calsamiglia, S., Ferret, A. \& Kamel, C., 2005. Screening for the effects of natural plant extracts at different $\mathrm{pH}$ on in vitro rumen microbial fermentation of a high-concentrate diet for beef cattle. J Anim Sci. 83, 2572-2579. doi: 10.2527/2005.83112572x

Cullen, S.P., Monahan, F.J. \& Callan, J.J., 2005.The effect of dietary garlic and rosemary on grower-finisher pig performance and sensory characteristics of pork. Irish. J. Agr. Food. Res. 44, 57-67.

Davies, Z.S., Mason, D., Brooks, A.E., Griffith, G.W., Merry, R.J. \& Theodorou, M.K., 2000. An automated system for measuring gas production from forage inoculated with rumen fluid and its use in determining the effect of enzymes on grass silage. Anim. Feed. Sci. Tech. 83, 205-221. https://doi.org/10.1016/S0377-8401 (99)00138-8

Devant, M., Ferret, A., Gasa, J., Calsamiglia, S. \& Casals, R., 2000. Effects of protein concentration and degradability on performance, ruminal fermentation and nitrogen metabolism in rapidly growing heifers fed high-concentrate diets from 100 to $230 \mathrm{~kg}$ body weight. J. Anim. Sci. 78, 1667-1676. https://doi.org/10.2527/2000.7861667x

Ferme, D., Banjac, M., Calsamiglia, S., Busquet, M., Kamel, C. \& Avgustin, G., 2004. The effect of plant extracts on microbial community structure in a rumen-stimulating continuous-culture system as revealed molecular profiling. Folia. Microbio. 49, 151-155. doi: 10.1007/bf02931391

Goering, H.K. \& Vansoest, P.J., 1970. Forage fibre analysis (Apparatus, reagents, procedures and some applications). Washington, DC: USDA Agricultural Handbook ARS-USDA, No. 379:1-20.

Hart, K.J., Yanez-Ruiz, D.R., Duval, S.M., Mcewan, N.R. \& Newbold C.J., 2007. Plant extracts to manipulate rumen fermentation. Anim. Feed. Sci. Tech. 147, 1-28. https://doi.org/10.1016/j.anifeedsci.2007.09.007

Hristov, A.N., Mcallister, T.A., Van Herk, F.H., Cheng, K.-J., Newbold, C.J. \& Cheeke, P.R., 1999. Effect of Yucca schidigera on ruminal fermentation and nutrient digestion in heifers. J. Anim. Sci. 77, $2554-2563$. doi:10.2527/1999.7792554x

Iberl, B., Winkler, G., Muller, B. \& Knobloch, K., 1990. Quantitative determination of allicin and alliin from garlic by HPLC. Planta Medica. 56, 320-326.

Kamel, C., Greathead, H.M.R., Tejido, M.J. \& Carro, M.D., 2008. Effect of allicin and diallyl disulphide on in vitro rumen fermentation on mixed diet. Anim. Feed. Sci. Tech. 145, 351-363. https://doi.org/10.1016/j.anifeedsci.2007.05.050

Kasuga, S., Uda, N., Ushijima M, Morihara, N. \& Itakura, Y., 2001. Pharmacologic activities off aged garlic extract in comparison with other garlic preparation. J. Nutr. 131,1080s-1084s. https://doi.org/10.1093/jn/131.3.1080S

Klevenhusen, F., Zeitz, J.O., Duval, S., Kreuzer, M. \& Soliva, C.R., 2011. Garlic oil and its principal component diallyl disulphide fail to mitigate methane, but improve digestibility in sheep. Anim. Feed. Sci. Tech. 166, 356-363. https://doi.org/10.1016/j.anifeedsci.2011.04.071

Kongmun, P., Wanapat, M., Pakde, P. \& Navanukraw, C., 2010. Effect of coconut oil and garlic powder on in vitro fermentation using gas production technique. Livest. Sci. 127, 38-44. https://doi.org/10.1016/j.livsci.2009.08.008

Kongmun, P., Wanapat, M., Pakdee, P., Navanukraw, C. \& Yu, Z., 2011. Manipulation of rumen fermentation and ecology of swamp buffalo by coconut oil and garlic powder supplementation. Livest. Sci. 135, 84-92.

Mackie, R.I. \& White, B.A., 1990. Recent advances in rumen microbial ecology and metabolism: potential impact on nutrient output. J. Dairy. Sci. 73, 2971-2995. doi: 10.1016/j.livsci.2010.06.131

Marshall, B.M. \& Levy, S.B., 2011. Food animals and antimicrobials impacts on human health. Clin Microbiol Rev. 24:718-733. doi: 10.1128/CMR.00002-11.

Martin, S.A. \& Macy, J.M., 1985. Effects of monensin, pyromelliticdimide and 2-bromoethanosulfonic acid on rumen fermentation in vitro. J. Anim. Sci. 60, 544-550. doi: 10.2527/jas1985.602544x

Mauricio, R.M., Mould, F.L., Dhanoa, M.S., Owen, E., Channa, K.S. \& Heodorou, M.K., 1999. A semi-automated in vitro gas production technique for ruminant feedstuff evaluation. Anim. Feed. Sci. Tech. 79, $321-330$. https://doi.org/10.1016/S0377-8401 (99)00033-4

McGuffey, R.K, Richardson, L.F. \& Wilkinson, J.I.D., 2001. Ionophores for dairy cattle. Current status and future outlook. J. Dairy. Sci. 84,194-203. https://doi.org/10.3168/jds.S0022-0302 (01)70218-4

National Research Council., 2001. Nutrient requirement of Dairy cattle. $7^{\text {th }}$ Revised Edition. Washington, DC: National Academy of Science.

Odongo, N.E., Bagg, R., Vessie, G., Dick, P., Or-Rashid, M.M., Hook, S.E., Gray, J.T., Kebreab, E., France, J. \& Mcbride, B.M. 2007. Long term effects of feeding monensin on methane production in lactating dairy cows. J. Dairy. Sci. 90:1781-1788. doi: 10.3168/jds.2006-708

Polyorach, S., Wanapat, M. \& Cherdthong, A., 2014. Influence of yeast fermented cassava chip protein (YEFECAP) and roughage to concentrate ratio on ruminal fermentation and microorganisms using in vitro gas production technique. Asian. Austral. J. Anim. 27, 36-45. doi: 10.5713/ajas.2013.13298

Reuter, H.D., Koch, J.P. \& Lawson, L., 1996. Therapeutic effects and applications of garlic and its preparations. In: H.P. Koch and L.D. Lawson (Eds.). Garlic: The Science and Therapeutic Application of Allium sativum L. and Related Species. Baltimore, MD: Williams and Wilkins, 135-212.

Revlin, R.S., 2001. Historical perspective on the use of garlic. J. Nutr. 131, 951s-954s. doi: 10.1093/jn/131.3.951S

Ross, Z.M., O'gara, E.A., Hill, D.J, Sleightholme, H.V. \& Maslin, D.J., 2001. Antimicrobial properties of garlic oil against human enteric bacteria: evaluation of methodologies and comparisons with garlic oil sulphides and garlic powder. Appl. Environ. Microbiol. 67,475-480. doi:10.1128/AEM.67.1.475-480.2001 
Russell, J.B., Sniffen, C.J. \& Van Soest, P.J., 1983. Effect of carbohydrate limitation on degradation and utilization of casein by mixed rumen bacteria. J. Dairy. Sci. 66, 763-775. doi:https://doi.org/10.3168/jds.S0022-0302(83)818566

SAS, 2009. Institute Inc. SAS/STAT® User's Guide, Cary, NC: SAS Institute Inc. Version 9. 2.

Theodorou, M.K., Williams, B.A., Dhanoa, M.S., Mcallan, A.B. \& France, J., 1994. A simple gas production method using a pressure transducer to determine the fermentation kinetics of ruminants fed. Anim. Feed. Sci. and Tech. 48, 185-197. doi: https://doi.org/10.1016/0377-8401(94)90171-6

Van Nevel, C.J. \& Demeyer, D.I., 1988. Manipulation of rumen fermentation. In: P.N. Hobson (Ed.). The rumen microbial ecosystem. London, UK: Elsevier Applied Science, 387-443.

Van Soest, P.J. \& Robertson, J.B., 1985. Analysis of forage and fibrous foods. A Laboratory Manual for Animal Science 613. Ithaca, New York: Cornell University.

Wanapat, M., Khejornsart, P., Pakdee, P. \& Wanapat, S., 2008. Effect of supplementation of garlic powder on rumen ecology and digestibility of nutrient in ruminants. J. Sci. Food. Agric. 88, $2231-2237$. https://doi.org/10.1002/jsfa.3333

Windisch, W., Rohrer, E. \& Schedle, K., 2009. Phytogenic feed additives to young piglets and poultry: Mechanisms and application. In: T. Steiner (Ed.). Phytogenic in Animal Nutrition: Natural Concepts to Optimize Gut Health and Performance. Nottingham, UK: Nottingham University Press, 19-38. doi:10.2527/jas.2007-0459

Yang, W.Z., Benchaar, C., Ametaj, B.N., Chaves, A.V., He, M.L. \& McAllister, T.A., 2007. Effects of garlic and juniper berry essential oils on ruminal fermentation and on the site and extent of digestion in lactating cows. J. Dairy Sci. 90, 5671-5681. doi:10.3168/jds.2007-0369

Yang, S. \& Carlson, K., 2004. Routine monitoring of antibiotics in water and wastewater with a radioimmunoassay technique. Water Res. 38:3155-3166. doi:10.1016/j.watres.2004.04.028 